Al-Mashlahah: Jurnal Hukum dan Pranata Sosial Islam, VOL : 07, NO : 1, Agustus 2019

DOI : 10.30868/am.v7i1.543

ISSN : 2339-2800 (Media Cetak)

ISSN : 2581-2556 (Media Online)

\title{
PERNIKAHAN BEDA AGAMA MENURUT IMAM MADZHAB DAN HUKUM POSITIF DI INDONESIA
}

\author{
J. Shodiq ${ }^{1}$, Misno ${ }^{2}$, dan Abdul Rosyid ${ }^{3}$ \\ ${ }^{1}$ Alumni Prodi Al-Ahwal Asy-Syaksiyah STAI Al Hidayah Bogor \\ ${ }^{2}$ Dosen Institut Agama Islam Sahid Bogor \\ ${ }^{3}$ Dosen Prodi Al-Ahwal Asy-Syakhshiyah STAI Al Hidayah Bogor
}

\begin{abstract}
Interfaith marriages are one source of problems in the household for a Muslim or maybe even among non-Muslims themselves and if this has really been done then the victim is the child who is most likely confused in determining his religion. This thesis discusses interfaith marriage according to Imam Madzhab and positive law in Indonesia. This study is motivated by a controversy regarding interfaith marriage in the opinion of the religious school priests and the positive law that applies in Indonesia. The objectives of this study are: 1) To find out the problems regarding interfaith marriage; 2) To know interfaith marriages according to positive law in Indonesia; 3) To find out the impact of interfaith marriages; and 4) To find out the reasons for the shari'a, it permits interfaith marriage. This type of research methods is a library research method, literature, and document study. This research is descriptive analysis, which describes the concept of the opinion of priests four schools and positive law in Indonesia.
\end{abstract}

Keywords: marriage, law, positive, difference, madzhab.

\begin{abstract}
ABSTRAK
Pernikahan beda agama adalah salah satu sumber problematika dalam rumah tangga bagi seorang muslim atau mungkin bahkan di kalangan non muslim itu sendiri dan jika hal ini telah benar-benar dilakukan maka yang menjadi korbannya adalah sang anak yang kemungkinan besar kebingungan dalam menentukan agamanya. Penelitian ini membahas tentang pernikahan beda agama menurut imam madzhab dan hukum positif di Indonesia. Kajian ini dilatarbelakangi oleh kontrofersi mengenai nikah beda agama menurut pendapat para imam madzhab serta hukum positif yang berlaku di indonesia. Tujuan dari penelitian ini adalah: 1) Mengetahui permasalahan tentang pernikahan beda agama; 2) Mengetahi pernikahan beda agama menurut hukum positif di Indonesia; 3) Mengetahui dampak dari pernikahan beda agama; dan 4) Mengetahui alasan syari'at membolehkan nikah beda agama. Jenis metode penelitian ini adalah metode library research (studi pustaka), observasi, dan studi dokumen. Penelitian ini bersifat deskriptif analisis, yaitu memaparkan konsep pendapat imam empat madzhab dan hukum positif di Indonesia.
\end{abstract}

Kata kunci: pernikahan, hukum, positif, perbedaan, madzhab. 


\section{A. PENDAHULUAN}

Islam mengatur sedemikian rupa tentang semua permasalahan manusia di antaranya adalah tentang pernikahan, pernikahan merupakan salah satu hal terpenting dalam keberlangsungan populasi manusia, tidak kalah pentingnya adalah bagaimana caranya agar kita dapat andil dalam mencetak dan menjadikan bibit-bibit generasi yang baik di masa depan yaitu dengan cara menjadi pribadi yang baik dan faham terhadap permasalahan agama kemudian mencari dan memilih wanitawanita yang sekufu, yaitu yang baik, yang seakidah dan faham pula terhadap permasalahan agama sebagai ibu dan pendidik bagi anak-anak kita nantinya. Lalu bagaimana jika pernikahan itu berbeda keyakinan yaitu berbeda agama dan bagaimana Islam memandang hal tersebut, serta bagaimana pendapat Imam Madzhab dan hukum positif di Indonesia?

Imam Abu Hanifah berpendapat bahwa bila wali dan perempuan yang akan dinikahkan dengan seorang lakilaki yang tidak sekufu, maka akad nikahnya tidak sah. Imam Malik berpendapat bahwa kekufuan yang dimaksud adalah dalam hal agama. ${ }^{1}$

Imam madzhab lain yaitu Imam Maliki, Imam Syafi'i, dan Imam Hambali berpendapat bahwa bila lakilaki muslim menikah dengan perempuan dzimmi (non muslim/kafir yang mendapat jaminan perlindungan), maka pernikahan tersebut tidak sah, kecuali disaksikan oleh dua orang muslim, sementara Hanafi berpendapat bahwa; sah dengan disaksikan dua orang dzimi saja. ${ }^{2}$

Wahbah Az-Zuhaili mengatakan; 'seorang muslim tidak boleh kawin (menikah) dengan seorang perempuan musyrik. Yaitu perempuan yang menyembah Allah bersama tuhan yang lain, seperti berhala, bintang-bintang, atau api, binatang."3 Allah dan RasulNya sangat menekankan untuk berhatihati dalam hal memilih pasangan hidup, sebab memilih pasangan yang salah dapat mendatangkan bencana bagi keluarga itu sendiri lantaran pasangan hidup yang dipilihnya tidak faham

\footnotetext{
1 Muhammad bin Abdurrahman AdDimasyqi. (2014). Fiqih Empat Madzhab. Bandung: Hasyimi. hlm. 322-323.

2 Muhammad bin Abdurrahman AdDimasyqi. (2014). hlm. 324-325.

${ }^{3}$ Wahbah Az-Zuhaili. (2011). Fiqih Islam wa Adillatuhu. Jakarta: Gema Insani. hlm. 147.
} 
permasalahan agama atau bahkan tidak seakidah yang kemudian akan melahirkan generasi-generasi yang tidak mendapatkan pendidikan Islam dengan baik, Allah S.W.T. melarang laki-laki mukmin menikah dengan wanita musyrik meskipun mereka (wanitawanita) itu sangat menarik, cantik ataupun kaya, kecuali jika mereka telah beriman.

Allah S.W.T. berfirman:

"Dan janganlah kamu menikahi wanita-wanita musyrik, sebelum mereka beriman. Sesungguhnya wanita budak yang mukmin lebih baik dari wanita musyrik, walaupun Dia menarik hatimu. dan janganlah kamu menikahkan orang-orang musyrik (dengan wanita-wanita mukmin) sebelum mereka beriman. Sesungguhnya budak yang mukmin lebih baik dari orang musyrik, walaupun Dia menarik hatimu. mereka mengajak ke neraka, sedang Allah mengajak ke surga dan ampunan dengan izin-Nya. dan Allah menerangkan ayatayat-Nya (perintah-perintahNya) kepada manusia supaya mereka mengambil pelajaran."

(Q.S. Al-Baqarah: 221)

Rasulullah S.A.W. bersabda:

"Wanita dinikahi karena empat alasan; karena harta, keturunan, kecantikannya, dan agamanya. Carilah yang taat beragama, niscaya kalian

beruntung." (H.R. Al-

Bukhari dan Muslim) ${ }^{4}$

Pada ayat dan hadits di atas disebutkan bahwa menikahi wanita yang beragama (Islam) sangat dianjurkan. Seorang muslim/muslimah yang cerdas sudah pasti tidak akan gegabah dalam menentukan pasangan hidupnya dia akan senantiasa berupaya dan berjuang untuk mencari pasangan suami/istri yang baik agama dan akhlaknya yang kelak menjadi pendidik sekaligus figur bagi anak-anaknya. Sebagaimana yang diungkapkan oleh seorang penulis buku, bahwa seorang anak akan menurut tarbiyah dan pendidikan yang diberikan kepadanya, sifat-sifat orang tua akan menurun kepada anak-anak mereka, ibarat kata pepatah "buah jatuh tidak akan jauh dari pohonnya”. Betapa banyak ketakwaan pada diri anak disebabkan dia mengikuti ketakwaan kedua orang tuanya atau salah seorang dari mereka. ${ }^{5}$

Pernikahan beda agama adalah salah satu sumber problematika dalam rumah tangga bagi seorang muslim atau

4 Abdul 'Adzhim Badawi. (2008). Fiqih Praktis Nikah. Tasikmalaya: Salwa Press. hlm. 11.

${ }^{5}$ Ummu Ihsan Choiriyah dan Abu Ihsan Al-Atsary. (2012). Mencetak Generasi Rabbani. Bogor: Darul Ilmi Publishing. hlm. 24. 
mungkin bahkan di kalangan non muslim itu sendiri dan jika hal ini telah benar-benar dilakukan maka yang menjadi korbannya adalah sang anak yang kemungkinan besar kebingungan dalam menentukan agamanya. Kaum liberalis dan pluralis di berbagai belahan dunia terutama di Indonesia sangat gencar dalam mengkampanyekan pernikahan beda agama ini dengan mengatasnamakan HAM (Hak Asasi Manusia) meskipun telah jelas bahwa hal tersebut di larang di Indonesia berdasarkan undang-undang. Dalam undang-undang Republik Indonesia Nomor 1 Tahun 1974 tentang Perkawinan terdapat pasal yang menyebutkan tentang larangan pernikahan beda agama di antaranya adalah Pasal 1, perkawinan ialah ikatan lahir batin antara seorang pria dengan seorang wanita sebagai suami isteri dengan tujuan membentuk keluarga (rumah tangga) yang bahagia dan kekal berdasarkan Ketuhanan Yang Maha Esa. $^{6}$

Kemudian Pasal 2 Ayat 1 perkawinan adalah sah, apabila

6 Tim Redaksi Nuansa Aulia. (2011). Kompilasi Hukum Islam. Bandung: Nuansa Aulia. hlm. 76. dilakukan menurut hukum masingmasing agama dan kepercayaannya itu. ${ }^{7}$

Abd. Shomad dalam hal ini menjelaskan, bahwa; Pasal 2 UU No. 1 Tahun 1974 meletakan fundamentum yuridis perkawinan nasional, yakni; dilakukan menurut hukum agama, dan di catat menurut perundang-undangan yang berlaku, pasal ini secara tegas menyatakan bahwa; perkawinan itu sah, apabila dilakukan menurut hukum agama, maka bagi WNI (Warga Negara Indonesia) yang beragama Islam yang hendak melakukan perkawinan supaya sah harus dilaksanakan menurut ketentuan Hukum Perkawinan Islam. Fiqih Munakahat atau Hukum Perkawinan Islam di Indonesia adalah peraturan khusus di samping peraturan umum yang telah diatur dalam UUP (Undang-Undang Perkawinan). ${ }^{8}$

Abdullah Siddik juga memberikan komentarnya bahwa Pasal 2 UUP ini sejiwa dengan Pasal 29 UUD 1945 yang memuat kewajiban bagi Negara RI untuk menjalankan hukum setiap agama yang ber-ketuhanan Yang Maha Esa,

\footnotetext{
${ }^{7}$ Tim Redaksi Nuansa Aulia. (2011). hlm. 76.

8 Abd. Shomad. (2012). Hukum Islam Penormaan Prinsip Syariah dalam Hukum Indonesia. Jakarta: Kencana Media Prenada Group. hlm. 258.
} 
kecuali unsur-unsur agama yang bertentangan dengan Pancasila. Jadi bagi orang-orang Islam tegas berlaku Hukum Islam. Anggapan yang menyatakan dengan berlakunya UUP ini Hukum Perkawinan Islam tidak berlaku lagi adalah tidak tepat, karena menurut ketentuan dalam Pasal 66 UUP Yang dianggap tidak berlaku lagi bukanlah peraturan sebelumnya mengenai perkawinan secara keseluruhan melainkan hanyalah hal-hal yang mengatur tentang perkawinan sejauh telah diatur dalm UUP, dalam hal yang belum atau tidak diatur dalam UUP ini, maka masih berlaku. ${ }^{9}$

Di dalam Al-Qur'an dikatakan bahwa seorang laki-laki muslim diperbolehkan untuk menikahi perempuan ahlul kitab. Perempuan ahlul kitab adalah perempuan yang percaya terhadap agama samawi, seperti orang Yahudi dan Nashrani yang mengimani Taurat dan Injil. $^{10}$ Allah S.W.T. berfirman dalam Surat Al-Ma'idah Ayat 5:

"Pada hari ini dihalalkan bagimu yang baik-baik. Makanan (sembelihan) orangorang yang diberi Al-Kitab itu

\footnotetext{
${ }^{9}$ Abd. Shomad. (2012). hlm. 258.

10 Wahbah Az-Zuhaili. (2011). hlm. 148.
}

halal bagimu, dan makanan kamu halal (pula) bagi mereka. (Dan dihalalkan mangawini) wanita yang menjaga kehormatan diantara wanita-wanita yang beriman dan wanita-wanita yang menjaga kehormatan di antara orang-orang yang diberi alkitab sebelum kamu, bila kamu telah membayar mas kawin mereka dengan maksud menikahinya, tidak dengan maksud berzina dan tidak (pula) menjadikannya gundikgundik. Barangsiapa yang kafir sesudah beriman (tidak menerima hukum-hukum Islam), maka hapuslah amalannya dan ia di hari kiamat termasuk orang-orang merugi."

Imam Syafi'i dan beberapa orang ulama berpendapat, siapa di antara bani Israil yang beragama Yahudi dan Nashrani, maka wanita-wanita mereka halal dinikahi dan hewan sembelihan mereka boleh dimakan. Sedang orang yang beragama dan Nashrani selain mereka (bani Israil), baik orang Arab maupun non Arab, maka wanita-wanita mereka tidak boleh dinikahi dan hewan sembelihan mereka tidak halal dimakan!. ${ }^{11}$

Meskipun demikian ada sebagian ulama berpendapat bahwa menikah

${ }^{11}$ Abu Malik Kamal bin As-Sayyid Salim. (2014). Shahih Fikih Sunnah. Jakata: Pustaka Azzam. hlm. 139. 
dengan perempuan ahlul kitab terlarang karena perempuan ahlul kitab mereka memang benar mengimani tentang keTuhanan kepada Allah S.W.T. akan tetapi mereka juga menyembah sembahan-sembahan yang lain yang dianggap sebagai Tuhan mereka. Di dalam Fiqih Sunnah karya Sayyid Sabiq dikatakan bahwa Ibnu 'Umar pernah ditanya orang tentang laki-laki muslim nikah dengan perempuan Nashrani atau Yahudi. Jawabnya:

Allah mengharamkan orang-orang mukmin nikah dengan perempuan musyrik. Sedangkan menurut saya tidak ada perbuatan musyrik yang lebih besar daripada perempuan yang mengatakan, Isa sebagai Tuhannya atau salah seorang oknum Tuhan. ${ }^{12}$

Sebagian ulama juga berpendapat bahwa menikahi perempuan ahlul kitab adalah makruh. Sulaiman Ahmad Yahya Al-Faifi mengatakan bahwa menikah dengan wanita ahlul kitab meskipun boleh, tetapi hukumnya makruh; karena tidak ada jaminan dirinya akan condong kepadanya (suami); malah hal itu bisa beresiko memfitnah di dalam hal agamanya, atau

12 Sayyid Sabiq. (1980). Fiqih Sunnah. Bandung: PT Al Ma’arif. hlm. 155-156. anggota keluarganya akan menguasai dia. Dan jika wanita Harbiyah, lebih makruh lagi, karena lebih besar lagi pengaruh Ahlul Harbi itu. ${ }^{13}$

Sebagian ulama lain mengambil hikmah dari sebab dibolehkannya lakilaki muslim menikahi wanita ahlul kitab, dikarenakan mereka masih mengimani beberapa prinsip yang ada di dalam Islam, berbeda halnya dengan wanita musyrik. Seorang pakar fikih kontemporer dari Mesir berkata; 'sebab dalam pembolehan kawin dengan perempuan ahli kitab berbeda halnya dengan perempuan musyrik adalah dia memiliki kesamaan keimanan pada beberapa prinsip yang asasi. Yang dimulai dengan pengakuan terhadap Tuhan, keimanan kepada para rasul dan hari kiamat, dengan segenap hisab dan siksaan yang ada di dalamnya. Adanya titik temu ini menyebabkan adanya komunikasi berdasarkan landasan ini, yang menjamin terciptanya kehidupan perkawinan yang biasanya lurus dengan mengharap keislaman perempuan tersebut karena secara general dia

13 Sulaiman Ahmad Yahya Al-Faifi. (2009). Ringkasan Fikih Sunnah Sayyid Sabiq. Jakarta: Pustaka Al-Kautsar. hlm. 442. 
beriman dengan kitab-kitab para nabi dan rasul." 14

Adapun wanita muslimah dalam hal ini dilarang oleh syari'at untuk menikah dengan laki-laki non muslim (kafir) baik laki-laki itu orang musyrik, mulhid (atheis) maupun ahlul kitab, hal ini mengacu kepada firman Allah S.W.T. dalam Surat Al-Mumtahanah Ayat 10 .

Salah satu keterangan yang dapat diambil dalam ayat Al-Mumtahanah Ayat 10 tesebut yaitu larangan Allah agar perempuan muslimah tidak dikawini oleh ahlul kitab (orang-orang kafir), karena dikhawatirkan akan dipengaruhi meninggalkan agamanya. Islam meninjau kemungkinan terjadinya hal tersebut, karena suamilah yang menjadi pemimpin dalam rumah tangganya, tentu saja ia dapat menggunakan hak otoritasnya untuk mmengajak keluarganya untuk menganut keyakinannya. ${ }^{15}$ Yang paling dominan melakukan pernikahan beda agama di Indonesia kebanyakan adalah mereka yang awam terhadap agama dan cenderung terhadap sifat keduniawian semata, sehingga mereka tidak

14 Wahbah Az-Zuhaili. (2011). hlm. 149.

15 Mahjuddin. (2012). Masa'il Al-Fiqh: Kasus-Kasus Aktual dalam Hukum Islam. Jakarta: Kalam Mulia. hlm. 48. menyadari akibat dari pernikahannya tersebut. Sebagian orang muslim mungkin faham tentang akibat pernikahan beda agama tersebut akan tetapi kebanyakan mereka tidak tahu bagaimana pendapat ulama madzhab dan hukum positif yang di sahkan di Indonesia.

Berdasarkan uraian di atas perlu diketahui bahwa imam madzhab bersepakat melarang laki-laki muslim untuk menikah dengan non muslimah (wanita kafir) kecuali non muslimah itu adalah ahlul kitab yang beragama samawi yaitu Nasrani atau Yahudi yang paham Taurat dan Injil. Sedangkan wanita muslimah dilarang menikah dengan laki-laki non muslim baik lakilaki itu ahlul kitab beragama samawi, Yahudi dan Nasrani atau laki-laki musyrik.

Telah dijelaskan bahwa hukum positif di Indonesai melarang adanya pernikahan beda agama sebagaimana yang tersebut di dalam undang-undang yang telah dipaparkan di atas.

Ada beberapa permasalahan yang terkait dengan masalah pernikahan beda agama menurut imam empat madzhab dan hukum positif di Indonesia, masalah 
yang dapat diidentifikasi antara lain adalah:

1. Bagaimana hukum pernikahan beda agama menurut imam madzhab?

2. Bagaimana hukum positif di Indonesia mengenai pernikahan beda agama menurut hukum Islam?

3. Apa saja dampak dari pernikahan beda agama?

\section{B. METODE PENELITIAN}

Penelitian ini merupakan penelitian kajian pustaka (library research), yaitu penelitian dengan cara mengkaji dan menelaah sumber-sumber tertulis dengan jalan mempelajari, menelaah, dan memeriksa bahan-bahan kepustakaan yang mempunyai relevansi dengan penelitian ini. Penelitian ini juga bersifat deskriptif analis, yaitu memaparkan konsep pendapat imam madzhab dan hukum positif di Indonesia, adapun data yang digunakan dalam penelitian ini berupa data kualitatif dengan metode normatif legal studi, yaitu informasi-informasi yang bersumber dari pendapat imam madzhab serta hukum positif di Indonesia, serta buku-buku lainya yang menunjang pada penelitian ini khususnya pada pembahasan hukum pernikahan beda agama dan hukum positif di Indonesia yang berlaku.

Dalam menganalisa data dan materi yang disajikan penyusun menggunakan analisa kualitatif dengan menggunakan cara berfikir induktif. Penyusun berusaha menganalisis mengenai hukum pernikahan beda agama yang di fatwakan oleh imam empat madzhab untuk kemudian menghubungkan terhadap hukum pernikahan beda agama menurut hukum positif di Indonesia.

Agar penyusunan data dapat dipertanggungjawabkan keabsahannya, maka penyusun melakukan beberapa langkah selama proses penelitian berlangsung: 1) Perpanjangan penelusuran data berupa perpanjangan waktu penelitian; 2) Trianggulasi data berupa trianggulasi sumber, trianggulasi teknik pengumpulan data dan waktu; dan 3) Pengecekan ulang data dari informan agar data yang diperoleh bisa dipertanggungjawabkan. Dalam hal ini proses pengecekan data tetap memperhatikan keabsahan data, hubungan dengan data lainnya, serta faktor lain yang mempengaruhi pemberian data oleh informan. 


\section{PEMBAHASAN}

Secara bahasa perkawinan atau pernikahan dalam literatur fikih berbahasa Arab disebut dengan dua kata, yaitu nikah (نكح), dan zawaj (زواج) kedua kata ini yang terpakai dalam kehidupan sehari-hari orang Arab dan banyak terdapat dalam Al-Qur'an dan Hadits Nabi. Kata na-ka-ha banyak terdapat dalam Al-Qur'an dengan arti kawin, ${ }^{16}$ seperti dalam Surat An-Nisa' Ayat 3:

"Dan jika kamu takut tidak akan dapat berlaku adil terhadap (hak-hak) perempuan yang yatim (bila kamu mengawininya), maka kawinilah wanita-wanita (lain) yang kamu senangi: dua, tiga atau empat. Kemudian jika kamu takut tidak akan dapat berlaku adil, maka (kawinilah) seorang saja, atau budakbudak yang kamu miliki. Yang demikian itu adalah lebih dekat kepada tidak berbuat aniaya."

Demikian pula banyak terdapat kata $z a$-wa-ja dalam Al-Qur'an dalam arti kawin, seperti pada surat Al-Ahzab Ayat 37:

Sedangkan secara istilah kata nikah berarti "bergabung” (ضم), "Hubungan

16 Amir Syarifuddin. (2009). Hukum Perkawinan di Indonesia. Jakarta: Kencana Prenada Media Grup. hml. 35-36. kelamin" (وطء), dan juga berarti "akad" (عقد), adanya tiga kemungkinan arti ini karena kata nikah yang terdapat dalam Al-Qur'an memang mengandung tiga arti kata tersebut. Kata nikah yang terdapat dalam Surat Al-Baqarah Ayat 230.

Menurut Abdul Shomad, kata perkawinan menurut istilah hukum Islam sama dengan kata "nikah" dan kata "zawaj". Nikah menurut bahasa mempunyai arti sebenarnya (hakikat) yakni, "dham" yang berarti menghimpit, atau berkumpul.

Nikah mempunyai arti kiasan yakni, "wathaa" yang berarti "setubuh" atau "akad" yang berarti mengadakan perjanjian pernikahan sehari-hari, nikah dalam arti kiasan lebih banyak dipakai dalam arti sebenarnya jarang sekali dipakai saat ini.

Menurut ahli ushul, arti nikah terdapat tiga macam pendapat, yakni 1) Imam Hanafi nikah arti aslinya adalah setubuh dan menurut arti majazi (metaporik) adalah dengannya menjadi halal hubungan kelamin antara pria dan wanita; 2) Imam Syafi'i nikah arti aslinya adalah akad yang dengannya menjadi halal hubungan kelamin antara pria dan wanita, sedangkan menurut arti 
majazi adalah setubuh; dan 3) Menurut Abdul Qosim Azzajjad, Imam Yahya, Ibnu Hazm, dan sebagian ahli ushul dari sahabat Abu Hanifah mengartikan nikah bersyarikat antara akad dan setubuh. ${ }^{17}$

Sementara menurut undang-undang Republik Indonesia Nomor. 1 Tahun 1974 Pasal 1 dalam Kompilasi Hukum Islam (KHI) menyebutkan, bahwa "Perkawinan ialah ikatan lahir batin antara seorang pria dengan seorang wanita sebagai suami isteri dengan tujuan membentuk keluarga (rumah tangga) yang bahagia dan kekal berdasarkan Ketuhanan Yang Maha Esa"18

Agama secara etimologi dalam bahasa Indonesia sama artinya dengan peraturan. Kata agama berasal dari bahasa Sansekerta 'a' berarti tidak dan 'gamma' berarti kacau, agama berarti tidak kacau. Agama semakna dengan kata "religion" (bahasa Inggris), "religie" (Belanda), "religio" (Latin), yang berarti mengamati, berkumpul/bersama, mengambil, dan menghitung.

Agama semakna juga degan kata "Ad-Dien" (Bahasa Arab) yang berarti cara, adat kebiasaan, peraturan, undangundang, perhitungan, hari kiamat, dan

\footnotetext{
${ }^{17}$ Abd. Shomad. (2012). hlm. 258-259.

${ }^{18}$ Tim Redaksi Nuansa Aulia. (2011). hlm.
} 76. nasihat. ${ }^{19}$ Sedangkan secara termonologis menurut Harun Nasution, agama adalah suatu sistem kepercayaan dan tingkah laku yang berasal dari suatu kekuatan yang ghaib.

Menurut Al-Syahrastani, agama adalah kekuatan dan kepatuhan yang terkadang biasa diartikan sebagai pembalasan dan perhitungan (amal perbuatan di akhirat). ${ }^{20}$ Menurut Prof. Dr. Bouquet, agama adalah hubungan yang tetap antara diri manusia dengan yang bukan manusia yang bersifat suci dan supernatur, dan yang bersifat berada dengan sendirinya dan yang mempunyai kekuasaan absolut yang disebut Tuhan. $^{21}$

Pengertian agama menurut berbagai agama:

Agama menurut agama Islam ialah, kata Islam berasal dari kata: salam yang artinya selamat, aman yang dimaksud sentosa, sejahtera: yaitu aturan hidup yang dapat menyelamatkan manusia di dunia dan di akhirat. ${ }^{22}$

${ }^{19}$ Abdullah Ali Yatim. (2007). Agama dan Ilmu Perbandingan. Bandung: Nuansa Aulia. hlm. 5 .

20 Abdullah Ali Yatim. (2007). hlm. 5.

21 Abu Ahmadi. (1984). Sejarah Agama. Solo: CV Ramadhani. hlm. 14.

${ }_{22}$ http://ading-aday.blogspot.com/p/blogpage.html, hari Rabu 12 Agustus 2015, pkl. 09:30 WIB. 
Dari pemaparan di atas dapat penulis simpulkan bahwa yang dimaksud dengan agama baik secara etimologi maupun terminologi adalah; suatu keyakinan yang baik yang tidak kacau atau berantakan (buruk) yang menjadi pedoman dan dapat menjadikan ummat manusia selamat, aman sentausa, sejahtera serta penuh ketenangan.

Menurut Huzaimah Tahido Yanggo yang dimaksud pernikahan beda agama adalah pernikahan antara laki-laki muslim dengan perempuan bukan muslimah atau sebaliknya. $^{23}$ Dalam buku Hukum Perkawinan di Indonesia yang ditulis oleh Amir Syarifuddin juga menjelaskan bahwa yang dimaksud dengan beda agama ialah perempuan muslimah dengan laki-laki nonmuslim dan sebaliknya laki-laki muslim dengan perempuan nonmuslim. Dalam istilah fikih disebut nikah dengan orang kafir. $^{24}$

Mazhab atau dalam bahasa Arab disebut al-mazahib, secara etimologi berasal dari kata: ذهبا - مذهبا - يذهب ـذذب dengan bentuk jamaknya مذاهب yang berarti الطريقة,المعتقد artinya aliran atau paham yang diikuti/dianut. ${ }^{25}$

${ }^{23}$ Huzaimah Tahido Yanggo. (2005). Masail Fiqhiyyah. Bandung: Penerbit Angkasa. hlm. 154.

${ }_{24}$ Amir Syarifuddin. (2009). hlm. 13

${ }^{25}$ Luis Ma'luf. (1986). Al-Munjid. Beirut: Daar Al-Masyriq. hlm. 240.
Sedangkan dalam Ensiklopedia Islam madzhab diartikan sebagai pendapat, kelompok atau aliran yang bermula dari pemikiran atau ijtihad seorang imam dalam memahami sesuatu baik filsafat, hukum fikih, teologi, dan sebagainya. Pemikiran ini kemudian diikuti oleh kelompok atau pengikutnya dan dikembangkan menjadi suatu aliran sekte atau ajaran. ${ }^{26}$

Adapula yang mengartikan mazhab sebagai tempat berjalan, aliran. Dalam istilah Islam berarti pendapat, faham atau aliran seorang alim besar dalam Islam yang disebut imam seperti mazhab Syafi'i, mazhab Maliki, dan lain sebagainya. ${ }^{27}$

Pendapat lain yang hampir serupa juga mengatakan bahwa madzhab: مذهب (ma-dza-ha-ba) adalah istilah dari bahasa Arab, yang berarti jalan yang dilalui dan dilewati, sesuatu yang menjadi tujuan seseorang baik konkrit maupun abstrak. Sesuatu dikatakan madzhab bagi seseorang jika cara atau jalan tersebut menjadi ciri khasnya. Menurut para ulama dan ahli fiqih, yang

${ }^{26}$ M. Bahri Ghazali. (1999). Ensikloedia Islam. Jakarta: PT Ihtiar Baru Van Hoeve. hlm. 214.

${ }^{27}$ M. Bahri Ghazali. (1992). Perbandingan Mazhab. Jakarta: PT Ihtiar Baru Van Hoeve. hlm 7 . 
dinamakan mazhab adalah metode (manhaj) yang dibentuk setelah melalui pemikiran dan penelitian, kemudian orang yang menjalaninya menjadikannya sebagai pedoman yang jelas batasan-batasannya, bagianbagiannya, dibangun di atas prinsipprinsip dan kaidah-kaidah. ${ }^{28}$

Dari pengertian diatas mengenai arti madzhab baik secara etimologi maupun secara terminologi, tentunya kita bisa memahami bahwa yang dimaksud dengan madzhab atau almazahib adalah suatu jalan, metode (manhaj) atau pendapat serta pandangan ulama yang dibentuk dan dijalani melalui pemikiran serta penelitian kemudian diikuti oleh suatu kelompok atau pengikutnya hingga menjadi suatu golongan atau aliran dengan batasanbatasan tertentu yang dibangun di atas prinsip dan kaidah-kaidahnya.

Hukum positif adalah kumpulan asas dan kaidah hukum tertulis yang pada saat ini sedang berlaku dan mengikat secara umum atau khusus dan ditegakkan oleh atau melalui pemerintah atau pengadilan dalam negara Indonesia. Hukum di Indonesia

28 https://id.wikipedia.org/wiki/Mazhab \#cite_note-mediamuslim-1, hari Selasa tgl 11 Agustus 2015 pkl. 13:30 WIB. merupakan campuran dari sistem hukum Eropa, hukum agama dan hukum adat. Sebagian besar sistem yang dianut, baik perdata maupun pidana, berbasis pada hukum Eropa kontinental, khususnya dari Belanda karena aspek sejarah masa lalu Indonesia yang merupakan wilayah jajahan dengan sebutan Hindia Belanda (NederlandschIndie). Hukum agama, karena sebagian besar masyarakat Indonesia menganut Islam, maka dominasi hukum atau Syari'at Islam lebih banyak terutama di bidang perkawinan, kekeluargaan, dan warisan. Selain itu, di Indonesia juga berlaku sistem hukum Adat yang diserap dalam perundang-undangan atau yurisprudensi, yang merupakan penerusan dari aturan-aturan setempat dari masyarakat dan budaya-budaya yang ada di wilayah Nusantara. ${ }^{29}$

Tiap-tiap bangsa memiliki hukumnya sendiri, seperti terhadap bahasa dikenal tata bahasa, demikian juga terhadap hukum dikenal juga tata hukum. Tiap-tiap bangsa mempunyai tata hukumnya sendiri.

Hukum merupakan positivasi nilai moral yang berkaitan dengan

29 Abdoel Djamali R. (2005). Pengantar Hukum Indonesia. Jakarta: PT RajaGrafindo Persada. hlm. 14. 
kebenaran, keadilan, kesamaan derajat, kebebasan, tanggung jawab, dan hati nurani manusia. Hukum sebagai positivasi nilai moral adalah legitimasi karena adil bagi semua orang. Salah satu kesimpulan dari studi yang dilakukan oleh lembaga-lembaga dunia, seperti Booz-Allen \& Hamilton, McKinsey, dan Bank Dunia terhadap kinerja perekonomian Indonesia adalah rendahnya praktik Good Corporate Governance (GCG). Secara umum, GCG sendiri berarti suatu proses dan struktur yang digunakan untuk mengarahkan dan mengelola bisnis dan akuntabilitas perusahaan dengan tujuan utama mempertinggi nilai saham dalam jangka panjang dengan tetap memperhatikan kepentingan stakeholders lain. Dari pengertian tersebut, selanjutnya dapat dijelaskan bahwa GCG tidak lain adalah permasalahan mengenai proses pengelolaan perusahaan, yang secara konseptual mencakup diaplikasikannya prinsip-prinsip transparancy, accountability, fairness, dan responsibility. ${ }^{30}$

30 http://rodlial.blogspot.com/2012/04/ makalah-substansi-hukum-positif-di.html, hari Selasa tgl 11 Agustus 2015 pkl. 14:30 WIB.
Pada saat baru lahir di tahun 1945, negara 'bayi' bernama Indonesia mengunifikasi serta mengkodifikasi hukum positif buatan Belanda yang diberlakukan bagi masyarakat di Hindia Belanda yang terdiri dari berbagai etnik saat itu - bangsa Eropa, bangsa Cina, dan bangsa Timur Jauh bukan Cina yaitu bangsa Arab dan India serta masyarakat pribumi/inlander bangsa Nusantara. Dasar dari peraturan Belanda tersebut sebenarnya adalah hukum buatan VOC (Verenige Oost Indische Companie), yang merupakan multinational company pertama di Nusantara. Perusahaan dagang multinasional milik kolonial Belanda yang dibentuk oleh 14 warga Belanda bagi manajemen penjajahan di negara jajahan di Asia Tenggara ditengah kemelut ekonomi dalam negeri Kerajaan Belanda yang terjerat hutang yang besar pasca perang dengan negaranegara tetangganya dan menuju kebangkrutan. Hukum khusus yang mereka buat tersebut memang khusus untuk diberlakukan bagi para inlander/masyarakat jajahan Belanda di Hindia Belanda. Artinya kita sekarang sedang terjajah oleh bangsanya sendiri. Sehingga tidak mengherankan sikap 
krusial pilihan hukum para penegak hukum Indonesia sampai hari ini masih memprihatinkan. Hukum harus ditegakkan dan keadilan harus dijujurkan - vivat justitia vereat mudus (walaupun langit akan runtuh hukum harus tetap ditegakkan). ${ }^{31}$

\section{Pernikahan Beda Agama Menurut Al-Qur'an dan As- Sunnah}

Al-Qur'an menyatakan pelarangan tentang pernikahan beda agama terhadap laki-laki muslim dengan wanita kafir yang musyrik dan juga melarang wanita-wanita muslimah menikah dengan laki-laki kafir, Allah S.W.T. berfirman dalam Surat AlBaqarah Ayat 221:

"Dan janganlah kamu menikahi wanita-wanita musyrik, sebelum mereka beriman. Sesungguhnya wanita budak yang mukmin lebih baik dari wanita musyrik, walaupun dia menarik hatimu. Dan janganlah kamu menikahkan orang-orang musyrik (dengan wanita-wanita mukmin) sebelum mereka beriman. Sesungguhnya budak yang mukmin lebih baik dari orang musyrik, walaupun dia menarik hatimu. Mereka mengajak ke neraka, sedang Allah mengajak ke surga dan ampunan dengan izin-Nya. Dan Allah menerangkan ayat-
ayat-Nya (perintah-perintahNya) kepada manusia supaya mereka mengambil pelajaran."

(Q.S. Al-Baqarah: 221)

Di sisi lain Al-Qur'an membolehkan laki-laki yang muslim menikah dengan wanita kafir (non Islam) akan tetapi yang diperbolehkan dinikahi hanya wanita kafir (non Islam) yang beragama samawi atau wanita ahlul kitab seperti Yahudi dan Nasrani sebagaimana yang telah Allah firmankan dalam Surat Al-Ma'idah Ayat 5:

"Pada hari ini dihalalkan bagimu yang baik-baik. Makanan (sembelihan) orangorang yang diberi Al Kitab itu halal bagimu, dan makanan kamu halal (pula) bagi mereka. (Dan dihalalkan mangawini) wanita yang menjaga kehormatan diantara wanitawanita yang beriman dan wanita-wanita yang menjaga kehormatan di antara orangorang yang diberi Al Kitab sebelum kamu, bila kamu telah membayar mas kawin mereka dengan maksud menikahinya, tidak dengan maksud berzina dan tidak (pula) menjadikannya gundik-gundik. Barangsiapa yang kafir sesudah beriman (tidak menerima hukumhukum Islam) maka hapuslah amalannya dan ia di hari kiamat termasuk orang-orang merugi."

\footnotetext{
${ }^{31}$ Abdoel Djamali R. (2005). hlm. 95.
} 
Adapun As-Sunnah mengenai hal ini tetap menganjurkan agar kaum muslimin dan muslimah agar tetap beruapaya mencari dan memilih pasangan suami atau istri yang seakidah tentunya yang agamanya baik, sebagaimana hadits bahwa Rasulullah S.A.W. bersabda: "Wanita dinikahi karena empat alasan; karena harta, keturunan, kecantikan, dan agamanya. Carilah yang taat beragama, niscaya kalian beruntung." (H.R. Al-Bukhari dan Muslim). ${ }^{32}$

Pertanyaannya; bukankah Allah S.W.T. menjelaskan bahwa boleh lakilaki muslim menikahi wanita kafir (non muslimah) ahlul kitab yang beragama samawi yaitu wanita dari kaum Yahudi dan Nasrani?. Jawabannya adalah; iya memang benar itu dibolehkan akan tetapi perlu diketahui bahwa pembolehan menikahi mereka wanitawanita ahlul kitab itu tidak bersifat anjuran dan hal ini juga telah dijelaskan oleh seorang sahabat Ibnu 'Umar radhiyallahu'anhum, bahwa Ibnu 'Umar pernah ditanya tentang laki-laki muslim nikah dengan perempuan Nashrani atau Yahudi. Jawabnya: Allah

32 Abdul 'Adzhim Badawi. (2008). hlm. 11. mengharamkan orang-orang mukmin nikah dengan perempuan musyrik. Sedangkan menurut saya tidak ada perbuatan musyrik yang lebih besar daripada perempuan yang mengatakan, Isa sebagai Tuhannya atau salah seorang oknum Tuhan, ${ }^{33}$ itu artinya menikah dengan wanita kafir (non muslimah) meskipun ahlul kitab yang beragama samawi baik itu dari kalangan kaum Yahudi maupun Nasrani tidaklah tepat.

\section{Pernikahan Beda Agama Menurut Imam Madzhab}

a. Pernikahan Beda Agama Menurut Madzhab Imam Abu Hanifah

Imam Abu Hanifah berpendapat bahwa perkawinan antara pria muslim dengan wanita musyrik hukumnya adalah mutlak haram, tetapi membolehkan mengawini wanita ahlul kitab (Yahudi dan Nasrani), sekalipun ahlul kitab tersebut meyakini trinitas, karena menurut mereka yang terpenting adalah ahlul kitab tersebut memiliki kitab samawi. Menurut mazhab ini yang dimaksud dengan ahlul kitab adalah siapa saja yang mempercayai seorang nabi dan kitab yang pernah diturunkan

33 Sayyid Sabiq. (1980). Fiqih Sunah. Bandung: PT Al-Ma’arih. hlm. 155-156. 
Allah S.W.T., termasuk juga orang yang percaya kepada Nabi Ibrahim alaihissalam dan Suhufnya dan orang yang percaya kepada nabi Musa AS dan kitab Zaburnya, maka wanitanya boleh dikawini. Bahkan menurut mazhab ini mengawini wanita ahlul kitab zimmi atau wanita kitabiyah yang ada di Darul Harbi adalah boleh, hanya saja menurut mazhab ini, perkawinan dengan wanita kitabiyah yang ada di darul harbi hukumnya makruh tahrim, karena akan membuka pintu fitnah, dan mengandung mafasid yang besar, sedangkan perkawinan dengan wanita ahlul kitab zimmi hukumnya makruh tanzih, alasan mereka adalah karena wanita ahlul kitab zimmi ini menghalalkan minuman arak dan menghalalkan daging babi.

Penulis menyimpulkan bahwa pendapat Imam Abu Hanifah tentang keharaman menikahi wanita musyrik karena mengacu kepada firman Allah S.W.T. dalam Surat Al-Baqarah Ayat 221:

"Dan janganlah kamu menikahi wanita-wanita musyrik, sebelum mereka beriman. Sesungguhnya wanita budak yang mukmin lebih baik dari wanita musyrik, walaupun dia menarik hatimu. Dan janganlah kamu menikahkan orang-orang musyrik (dengan wanita-wanita mukmin) sebelum mereka beriman. Sesungguhnya budak yang mukmin lebih baik dari orang musyrik, walaupun dia menarik hatimu. Mereka mengajak ke neraka, sedang Allah mengajak ke surga dan ampunan dengan izin-Nya. Dan Allah menerangkan ayatayat-Nya (perintah-perintahNya) kepada manusia supaya mereka mengambil pelajaran".

(Q.S. Al-Baqarah: 221)

Akan tetapi pendapat madzhab Imam Hanafi membolehkan mengawini wanita ahlul kitab (Yahudi dan Nasrani) hal ini juga karena merujuk kepada firman Allah S.W.T. dalam Surat AlMa'idah Ayat 5 yang telah disebutkan sebelumnya.

Akan tetapi pembolehan tersebut bersifat makruh sebagaimana yang disampaikan oleh Wahbah Az-Zuhaili, bahwa mazhab Hanafi berpendapat, seorang muslim makruh menikah dengan perempuan Ahli Kitab dan ahli dzimmah. Karena Umar radhiyallahu 'anhu berkata kepada orang-orang yang kawin dengan perempuan ahli kitab, "Ceraikanlah mereka”. Maka para sahabat radhiyallahu 'anhum menceraikan mereka, kecuali Hudzaifah radhiyallahu 'anhu. Kemudian, Umar radhiyallahu 'anhu berkata kepadanya, "Ceraikanlah dia." Maka Hudzaifah 
bertanya, "Apakah kamu bersaksi bahwa dia haram?" Umar kembali berkata kepadanya, "Dia minum minuman keras." Hudzaifah kembali berkata "Aku telah mengetahui dia minum minuman keras, akan tetapi dia halal bagiku." Setelah lewat beberapa waktu, dia ceraikan istrinya tersebut. Lalu ada orang yang berkata kepadanya, "Mengapa kamu tidak menceraikannya manakala Umar memerintahkan hal itu kepadamu?” Dia menjawab, “Aku tidak mau manusia melihat aku melakukan suatu perkara yang tidak selayaknya aku lakukan". ${ }^{34}$ Bisa jadi, hatinya menyayanginya, karena dia memesona. Bisa juga karena mereka berdua telah mempunyai anak, dan dia menyayanginya. Sedangkan perempuan ahli harb (kafir yang memerangi umat Islam), menurut mazhab Hanafi haram untuk dikawini, jika dia berada di darul harb (wilayah konflik); karena mengawininya akan membuka pintu fitnah. $^{35}$

b. Pernikahan Beda Agama Menurut Madzhab Imam Malik Madzhab Maliki tentang perkawinan lintas agama ini mempunyai dua pendapat, yaitu 1) menikah dengan

\footnotetext{
${ }^{34}$ Wahbah Az-Zuhaili. (2011). hlm. 272.

${ }^{35}$ Wahbah Az-Zuhaili. (2011). hlm. 273.
}

wanita kitabiyah hukumnya makruh mutlak, baik dzimmiyah (wanita-wanita non-muslim yang berada diwilayah atau negeri yang tunduk pada hukum Islam) maupun wanita harbiyah, namun makruhnya menikahi wanita harbiyah lebih besar. Akan tetapi jika dikhawatirkan bahwa si isteri yang kitabiyah ini akan mempengaruhi anakanaknya dan meninggalkan agama ayahnya, maka hukumnya haram; dan 2) Tidak makruh mutlak karena ayat tersebut tidak melarangsecara mutlaq. Metodologi berfikir madzhab maliki ini menggunakan pendekatan sad alzariyan (menutup jalan yang mengarah kepada kaemafsadatan), jika dikhawatirkan kemafsadatan yang akan muncul dalam perkawinan beda agama ini, maka diharamkan. ${ }^{36}$

c. Pernikahan Beda Agama
Menurut Madzhab Imam Syafi'i
Imam Syafi'i berkata; Allah tabarokawataala berfirman dalam AlMumtahanah Ayat 10, setelah itu turunlah rukhsah (keringanan) yang menghalalkan wanita-wanita merdeka dari kalangan ahli kitab hal ini sebagaimana yang dijelaskan Allah

36 Abdul Aziz Muhammad Azzam dan Abdul Wahab Sayyed Hawwas. (2009). Fiqh Munakahat. Jakarta: Amzah. hlm. 37. 
S.W.T. dalam Surat Al-Ma'idah Ayat 5 sebelumnya.

Ketetapan Allah Subhanahu wataala yang membolehkan menikahi wanita-wanita merdeka di kalangan ahli kitab merupakan dalil yang mengharamkan menikahi wanita-wanita budak mereka, karena telah dikenal dalam bahasa; apabila suatu sifat disebutkan dalam kalimat yang berkonotasi penghalalan atau pengharaman, maka hal ini menjadi dalil bahwa yang berada di luar sifat tersebut, tidak masuk dari kalimat tadi. $^{37}$

Beliau (Imam Syafi'i) juga berpendapat bahwa apabila seorang wanita masuk Islam atau dilahirkan dalam keadaan Islam, atau salah seorang dari kedua orang tuanya masuk Islam, sementara da masih anak-anak dan belum mencapai usia balig. Maka haram atas setiap lelaki musyrik, ahli kitab, atau penyembah berhala untuk menikahinya dalam segala keadaan. Apabila kedua orang tuanya musyrik, lalu disebutkan kepadanya sifat-sifat Islam, dan ia memahaminya, maka saya melarang wanita di nikahi oleh laki-laki musyrik.
Namun bila disebutkan kepadanya sifatsifat Islam namun ia tidak memahaminya, maka saya lebih menyukai untuk laki-laki musyrik dilarang untuk menikahinya.

Imam Syafi'i juga berpendapat bahwa dihalalkan menikahi wanitawanita merdeka Ahli kitab bagi setiap muslim, karena Allah S.W.T. menghalalkan mereka tanpa pengecualian. Wanita-wanita Ahli kitab yang merdeka dan boleh dinikahi adalah pengikut dua kitab yang masyhur yakni; Taurat dan Injil dan mereka adalah Yahudi dan Nasrani.

Adapun Majusi, tidak masuk dalam golongan itu. Dihalalkan pula menikahi wanita-wanita dari golongan Syabiun dan Samirah dari kalangan yahudi dan Nasrani yang dihalalkan mengawini wanita mereka dan memakan hewan sembelihan mereka. Namun bila diketahui bahwa mereka menyelisihi orang-orang yang menghalalkan apa yang dihalalkan dalam al kitab dan mengharamkan apa yang diharamkannya, maka pada kondisi demikian diharamkan menikahi wanitawanita mereka sebagaimana 
diharamkannya menikahi wanita-wanita Majusi. $^{38}$

$\begin{array}{lrr}\text { d. Pernikahan } & \text { Beda } & \text { Agama } \\ \text { Menurut } & \text { Madzhab } & \text { Imam } \\ \text { Hambali } & & \end{array}$

Mazhab Hambali mengemukakan bahwa haram menikahi wanita-wanita musyrik, dan boleh menikahi wanita Yahudi dan Narani. Mazhab ini lebih kebanyakan pengikutnya cenderung mendukung pendapat guru Ahmad bin Hambal, yaitu Imam Syafi'i. Tetapi tidak membatasi, bahwa yang termasuk ahlu al-kitab adalah Yahudi dan Nasrani dari Bangsa Israel saja, tetapi menyatakan bahwa wanita-wanita yang menganut agama Yahudi dan Nasrani sejak saat Nabi Muhammad belum diutus menjadi Rasul. ${ }^{39}$

Berdasarkan uraian di atas, telah dijelaskan bahwa ulama Imam Madzhab sepakat untuk mengharamkan pernikahan antara laki-laki muslim dengan wanita musyrik dan membolehkan pernikahan antara lakilaki muslim dengan wanita ahlul kitab yakni Yahudi dan Nasrani. Akan tetapi, yang dimaksud oleh Imam Madzhab tentang wanita ahlul kitab (Yahudi dan Nasrani) di sini adalah karena wanita

\footnotetext{
${ }^{38}$ Imam Syafi'i. (2010). hlm. 433.

${ }^{39}$ Imam Syafi'i. (2010). hlm. 325.
}

ahlul kitab pada zaman dahulu berbeda dengan wanita ahlul kitab pada zaman sekarang.

Pada zaman dahulu wanita ahlul kitab mengimani kitab-kitab mereka yang belum banyak adanya perubahan dan wanita ahlul kitab pada zaman dahulu tidak berpengaruh terhadap pemikiran dan keyakinan laki-laki muslim (suami). Adapun pada saat ini, mereka wanita ahlul kitab mayoritas tidak memahami isi dan kandungan kitab-kitab mereka yang sesungguhnya, karena sudah banyaknya perubahan. Dengan demikian, penulis menyimpulkan bahwa pendapat Imam Madzhab tentang pembolehan pernikahan antara laki-laki muslim dengan wanita ahlul kitab hanya sebatas pada zaman mereka. Jika dianalisis berdasarkan apa yang telah disebutkan di atas sesuai dengan realita sekarang, maka sudah barang tentu Imam Madzhab akan mengharamkan pernikahan beda agama tanpa terkecuali.

\section{Perkawinan Beda Agama dalam Hukum Indonesia}

a. Pengertian Perkawinan Menurut UUP

Menurut Pasal 1 UU No. 1 Tahun 1974: Perkawinan adalah ikatan lahir batin antara seorang pria dan seorang wanita sebagai suami istri dengan 
tujuan membentuk keluarga atau rumah tangga yang bahagia dan kekal berdasarkan Ketuhanan Yang Maha Esa. Kata "ikatan lahir batin" dalam pengertian tersebut dimaksudkan bahwa perkawinan itu tidak hanya cukup dengan adanya ikatan lahir saja, atau hanya dengan ikatan batin saja, namun harus keduanya ada dalam perkawinan. Ikatan lahir dapat dimaknai bahwa perkawinan adalah ikatan yang dapat dilihat, artinya: adanya suatu hubungan hukum antara seorang pria dengan seorang wanita untuk hidup bersama, sebagai suami isteri. Ikatan ini dapat juga disebut sebagai "ikatan formal" yakni hubungan formal yang mengikat dirinya, orang lain dan masyarakat. Sedangkan "ikatan batin" dapat dimaknai sebagai hubungan yang tidak formil, artinya suatu ikatan yang tidak dapat dilihat, namun harus ada karena tanpa adanya ikatan batin dalam perkawinan maka ikatan lahir akan rapuh. $^{40}$

Pengertian di atas dapat mengandung beberapa aspek: pertama: aspek yuridis, karena di dalamnya terdapat ikatan lahir atau formal yang

40 Saleh, K. Watjik. (1992). Hukum Perkawinan Indonesia. Jakarta: Ghalia. hlm. 1415. melahirkan hubungan hukum antara suami istri; kedua: aspek social, dimana perkawinan merupakan hubungan yang mengikat dirinya, orang lain dan masyarakat; ketiga: aspek religius, yaitu dengan adanya term berdasarkan Ketuhanan Yang maha Esa sebagai dasar dalam pembentukan keluarga yang kekal dan bahagia. ${ }^{41}$

Perkawinan sebagai salah satu perjanjian yang merupakan perbuatan hukum, mempunayi akibat hukum. Adanya akibat hukum penting sekali hubungannya dengan sah tidaknya perbuatan hukum itu. Dalam Pasal 2 UUP disebutkan syarat sahnya perkawinan, yaitu: (1) Perkawinan adalah sah, apabila dilakukan menurut hukum masing-masing agamanya dan kepercayaannya itu; (2) Tiap-tiap perkawinan dicatat menurut peraturan perundang-undangan yang berlaku.

Dalam Pasal ini terdapat penegasan bahwa perkawinan, baru dapat dikategorikan sebagai perbuatan hukum yang sah apabila dilakukan menurut ketentuan agama dan kepercayaan masing-masing, sebagaimana dalam penjelasan Pasal 2 UUP bahwa tidak

41 Sri Wahyuni. (2011). Kontroversi Perkawinan Beda Agama di Indonesia. Media Syariah, Vol. XIII. hlm. 194. 
ada perkawinan di luar hukum masingmasing agama dan kepercayan itu. Hal ini sesuai dengan Pasal 29 UUD 1945: (1) Negara berdasarkan Ketuhanan Yang Maha Esa; (2) Negara menjamin kemerdekaan tiap-tiap penduduk untuk memeluk agamanya masing-masing dan untuk beribadah menurut agamanya dan kepercayaannya itu. ${ }^{42}$

b. Pengertian Perkawinan Beda Agama dalam Hukum Indonesia

Di Indonesia, perkawinan beda agama, sebelum lahirnya UUP No. 1 Tahun 1974 dikenal dengan sebutan "Perkawinan Campur", sebagaimana diatur pertama kali dalam Regeling op de gemengde Huwelijken, Staatblad 1898 No. 158, yang merupakan Peraturan Perkawinan Campur/PPC). Dalam PPC tersebut terdapat beberapa ketentuan tentang perkawinan campur (perkawinan beda agama):

Pasal 1: Pelangsungan perkawinan antara orang-orang yang di Hindia Belanda tunduk kepada hukum yang berbeda, disebut Perkawinan Campur.

Pasal 6 Ayat (1): Perkawinan campur dilangsungkan menurut hukum yang berlaku atas suaminya, kecuali izin para

\footnotetext{
${ }^{42}$ Sri Wahyuni. (2011). hlm. 195.
}

calon mitra kawin yang selalu disyaratkan.

Pasal 7 Ayat (2): Perbedaan agama, golongan, penduduk atau asal usul tidak dapat merupakan halangan pelangsungan perkawinan.

Pasal-pasal tersebut di atas menegaskan tentang pengaturan perkawinan beda agama, bahkan disebutkan perbedaan agama tidak dapat dijadikan alasan utnuk mencegah terjadinya perkawinan.

PPC tersebut dikeluarkan secara khusus oleh Pemerintah Kolonial Belanda guna mengantisipasi perbedaan golongan yang tertuang dalam Indische Staats Religing (ISR) yang merupakan Peraturan Ketatanegaran Hindia. Pada Pasal 163 golongan penduduk dibedakan menjadi tiga golongan yaitu: golongan Eropa (termasuk di dalamnya Jepang); golongan pribumi (Indonesia) dan golongan Timur Asing kecuali yang beragama Kristen. ${ }^{43}$

Perkawinan Campur sebagaimana dimaksud pada PPC S. 1898 No. 158 di atas, tidak dikenal dalam UU No. 1 Tahun 1974. Pasal yang dijadikan

\footnotetext{
43 Mudiarti Trisnaningsih. (2007). Relevansi Kepastian Hukum dalam Mengatur Perkawinan Beda Agama di Indonesia. Bandung: Penerbit Utomo. hlm. 57.
} 
landasan perkawinan beda agama pada UUP adalah Pasal 2 Ayat (1): Perkawinan adalah sah, apabila dilakukan menurut hukum masingmasing agamanya dan kepercayaannya itu; dan Pasal 8 huruf (f): perkawinan dilarang (f): mempunyai hubungan yang oleh agamanya atau peraturan lain yang berlaku dilarang kawin; serta Pasal 57: yang dimaksud dengan perkawinan campur dalam Undang-undang ini ialah perkawinan antara dua orang yang di Indonesia tunduk pada hukum yang berlainan, karena perbedaan kewarganegaraan dan salah satu pihak berkewarganegaraan Indonesia.

c. Status Hukum Perkawinan Beda Agama dalam UUP

Perkawinan beda agama menurut pemahaman para ahli dan praktisi hukum dalam Undang-undang No. 1 Tahun 1974 secara garis besar dapat dijumpai tiga pandangan:

Pertama, perkawinan beda agama tidak dapat dibenarkan dan merupakan pelanggaran terhadap UUP Pasal 2 Ayat (1): Perkawinan adalah sah, apabila dilakukan menurut hukum masingmasing agamanya dan kepercayaannya itu; dan Pasal 8 hurup (f): bahwa perkawinan dilarang antara dua orang yang mempunyai hubungan yang oleh agamanya atau peraturan lain yan berlaku, dilarang kawin. Maka dengan pasal ini, perkawinan beda agama dianggap tidak sah dan batal demi hukum.

Kedua, perkawinan beda agama adalah diperbolehkan, sah dan dapat dilangsunkan karena telah tercakup dalam perkawinan campuran, sebagaiman termaktub dalam Pasal 57 UUP, yaitu dua orang yang di Indonesia tunduk pada hukum yang berlainan. Menurut pandangan kedua ini, pasal tersebut tidak saja mengatur perkawinan antara dua orang yang memiliki kewarganegaran yang berbeda, akan tetapi juga mengatur perkawinan antara dua orang yang berbeda agama. Menurutnya, pelaksanaannya dilakukan menurut tata cara yang diatur oleh Pasal 6 PPC: (1) Perkawinan campur dilangsungkan menurut hukum yang berlaku untuk suami, kecuali izin dari kedua belah pihak bakal mempelai, yang seharusnya ada, dengan merujuk pada Pasal 66 UUP.

Ketiga. UUP tidak mengatur masalah perkawinan antaragama. Oleh karena itu, apabila merujuk Pasal 66 UUP yang menekankan bahwa 
peraturan-peraturan lain yang mengatur tentang perkawinan, sejauh telah diatur dalam unadang-undang ini, maka dinyatakan tidak berlaku lagi. Namun karena UUP belum mengaturnya, maka peraturan-peraturan lama dapat diberlakukan kembali, sehingga masalah perkawinan beda agama harus berpedoman kepada peraturan pekawinan campur (PPC) ${ }^{44}$ Perkawinan tidak dapat dibiarkan begitu saja, sebab akan mendorong terjadinya perzinahan terselubung melalui pintu kumpul kebo.

Di sisi lain, mayoritas masyarakat Muslim di Indonesia berpandangan bahwa UUP tidak perlu disempurkan dengan mencantumkan hukum perkawinan beda agama dalam undangundang tersebut, sebab menurut mereka, Undang-undang No. 1 Tahun 1974 telah mengatur hukum perkawinan beda agama secara jelas dan tegas. Ungkapan ini ada benarnya, karena umat Islam sebagai penduduk mayoritas di Indonesia merasa diuntungkan oleh Pasal 2 Ayat (1) UUP tersebut, karena dengan pasal tersebut tertutuplah

${ }^{44}$ Lihat UUP No. 1 Tahun 1974 dan Abdul Halim Berkatullah dan Teguh Prasetyo. (2006). Hukum Islam Menjawab Tantangan Zaman yang Terus Berkembang. Yogyakarta: Pustaka Pelajar. hlm. 147-148. kemungkinan untuk melakukan perkawinan secara "sekuler", dan tertutup pula kemungkinan seorang wanita muslimah untuk menikah dengan laki-laki non muslim, demikian halnya perkawinan seorang laki-laki muslim dengan perempuan musyrik, karena pernikahan tersebut dilarang (dianggap tidak sah) menurut hukum Islam. Sebenarnya, dengan adanya larangan untuk melangsungkan pernikahan beda agama tersebut, merupakan masalah penting bagi umat Islam karena peraturan perkawinan peninggalan Belanda (PPC) mengizinkan penduduk Indonesia

ntuk melakuan perkawinan beda agama. $^{45}$

\section{Perkawinan Beda Agama dalam Hukum Positif di Indonesia}

Perkawinan beda agama dalam hukum positif di Indonesia diatur secara eksplisit dalam Pasal 40 huruf (c) yang menyatakan bahwa dilarang melangsungkan perkawinan antara seorang pria dengan seorang wanita karena keadaan tertentu; diantaranya, karena seorang wanita yang tidak beragama Islam. Dalam Pasal 44 disebutkan bahwa seorang wanita Islam

\footnotetext{
${ }^{45}$ Sri Wahyuni. (2011). hlm. 196.
} 
dilarang melangsungkan perkawinan dengan seorang pria yang tidak beragama Islam.

Berdasarkan dua pasal di atas, dapat dikatakan bahwa menurut KHI, seorang wanita non muslim apa pun agama yang dianutnya tidak boleh dinikahi oleh seorang pria yang beragama Islam, dan seorang wanita muslim tidak boleh dinikahi oleh seorang pria non muslim, baik dari kategori ahli kitab atau pun bukan ahli kitab.

Secara struktur pembahasan KHI yang menempatkan status hukum perkawinan beda agama dalam bab yang membahas tentang "larangan perkawinan", jika dicermati, dapat dikategorikan sebagai pembaharuan yang cukup berani. Pembaharuan tersebut tentu ditetapkan setelah melalui penyatuan pendapat melalui beberapa jalur, yaitu: a) Jalur penelaahan kitabkitab fikih, yang dilakukan dengan melibatkan tujuh IAIN yang tersebar di seluruh Indonesia, khususnya Fakultas Syariah. Dalam penelaahan kitab-kitab fikih tersebut, para pihak telah melakukannya dengan melakukan penelitian terhadap sejumlah kitab-kitab induk fikih dari berbagai kecenderungan mazhab yang ada; b) Jalur wawancara dengan ulama-ulama yang mempunyai keahlian di bidang hukum Islam (fikih) yang tersebar di sepuluh lokasi wilayah PTA, yaitu: Banda Aceh, Medan, Padang, Palembang, Bandung, Surakarta, Surabaya, Banjarmasin, Ujung Pandang (Makassar), dan Mataram; c) Jalur Yuriprudensi Peradilan Agama, dilakukan di Direktorat Pembinaan Badan Peradilan Agama Islam terhadap sepuluh Himpunan Putusan PA; dan d) Jalur studi banding ke Marokko, Turki dan Mesir oleh tim dari Kemenag RI (H. Marani Basran dan Mukhtar Zarkasyi). ${ }^{46}$

\section{Hikmah Pernikahan Beda}

\section{Agama}

Hikmah dari sebab dibolehkannya laki-laki muslim menikahi wanita ahlul kitab, dikarenakan mereka masih mengimani beberapa prinsip yang ada di dalam Islam, berbeda halnya dengan wanita musyrik. Seorang pakar fiqih kontemporer dari mesir berkata; 'sebab dalam pembolehan kawin dengan

${ }^{46}$ Direktorat Pembinaan Badan Peradilan Agama Islam, Direktorat Jenderal Pembinaan Kelembagan Islam Departemen Agama. (1985). Kenang-kenangan Seabad Peradilan Agama di Indonesia. Jakarta: Depag RI. hlm. 166-168. 
perempuan ahli kitab berbeda halnya dengan perempuan musyrik adalah, dia memiliki kesamaan keimanan pada beberapa prinsip yang asasi. Yang dimulai dengan pengakuan terhadap Tuhan, keimanan kepada para rasul dan hari kiamat, dengan segenap hisab dan siksaan yang ada di dalamnya. Adanya titik temu ini menyebabkan adanya komunikasi berdasarkan landasan ini, yang menjamin terciptanya kehidupan perkawinan yang biasanya lurus dengan mengharap keislaman perempuan tersebut karena secara general dia beriman dengan kitab-kitab para nabi dan rasul." 47

Menurut Wahbah Az-Zuhaili; hikmah nikahnya seorang laki-laki muslim dengan seorang perempuan yahudi dan Nasrani bukan sebaliknya adalah, orang Muslim, beriman terhadap semua rosul dan dengan semua agama dalam asalnnya yang benar yang pertama, maka tidak ada bahaya dari suami terhadap aqidah dan perasaan istri. Sedangkan orang yang non Muslim yang tidak percaya terhadap Islam, terdapat bahaya yang mengintai yang membuat istrinya terpengaruh terhadap agamanya, perempuan biasanya mudah terpengaruh dan menurut. Dalam pernikahannya terdapat pengorbanan bagi perasaan dan akidahnya. $^{48}$

\section{Dampak Pernikahan Beda Agama Terhadap Keyakinan Anak}

Perbedaan agama dalam perkawinan dapat menimbulkan tekanan psikologis, berupa konflik kejiwaan, yang pada gilirannya mengakibatkan disfungsi perkawinan itu sendiri. Jika terjadi konflik perbedaan agama yang tidak dapat diselesaikan, suami atau istri kemungkinan tidak akan mengamalkan ajaran agama yang dianutnya, tetapi memilih pola hidup sekuler. Pola hidup sekuler akan menimbulkan konflik baru yang sulit diatasi, dan dapat menjurus kepada konflik keluarga.

Perkawinan bukan hanya ikatan antara individu, tetapi juga ikatan antara dua keluarga. Artinya, perkawinan itu melibatkan keluarga masing-masing pihak berada pada posisi yang sulit. Sebab, jika salah satu pihak (suami dan istri) pindah agama dan memakai tata cara salah satu agama maka akibat yang timbul adalah reaksi pihak keluarga. Konsekuensinya adalah pihak yang berpindah agama akan terkucil dari

\footnotetext{
${ }^{47}$ Wahbah Az-Zuhaili. (2011). hlm. 14.
}

${ }^{48}$ Wahbah Az-Zuhaili. (2011). hlm. 150. 
keluarga dan masyarakat dan secara tidak langsung juga agama. Jika terjadi krisis perkawinan, dia sulit diterima dalam lingkungan keluarganya karena dianggap telah murtad.

Keimanan suami atau istri terhadapnya bukan semakin bertambah melainkan semakin melemah. Demi "toleransi" dan "kerukunan", masingmasing mereka melepaskan prinsipprinsip aqidah agamanya sendiri sehingga terjadi pendangkalan iman, atau mungkin "konflik keimanan", dapat menimbulkan depresi akibat perasaan bersalah dan berdosa. ${ }^{49}$

Dampak psikologis lainnya dari perkawinan antar agama adalah perkembangan pertumbuhan anak. Perbedaan agama antara ayah dan ibu dapat membingungkan anak dalam hal memilih agama, apakah ia memilih agama ayahnya atau agama ibunya. Pengertian "toleransi dan kerukunan beragama" tidak berarti bagi pertumbuhan keagamaan dalam diri anak, bahkan besar kemungkinan anak memilih tidak beragama sama sekali (ateis). Di sinilah letak peran komitmen

49 Dadang Hawari. (1997). Ilmu Kedokteran jiwa dan Kesehatan Jiwa. Yogyakarta: Dana Bhakti Prima Yasa. hlm. 217-218. keagamaan ayah dan ibu dalam menentukan agama anak-anak, sebagaimana disabdakan Rasulullah S.A.W.: "Setiap anak dilahirkan dalam keadaan suci (fitrah), kedua orang tuanyalah yang menjadikannya sebagai Yahudi, Nasrani, atau Majusi". 50

Dari tataran pemikiarn di atas, ada satu hal yang perlu digarisbawahi, bahwa perkawinan antar agama menimbulkan dampak negatif psikologis terhadap kedua belah pihak (suami-istri) serta perkembangan pertumbuhan keagamaan dalam diri anak. Itulah sebabnya, Islam menganjurkan perkawinan harus seagama (Islam), sebagaimana disabdakan Rasulullah saw: "Wanita itu dinikahi karena empat perkara; karena hartanya, karena keturunannya, karena kecantikannya, dan karena agamanya. Akan tetapi utamakanlah yang beragama agar engkau memperoleh kebahagiaan."

\section{Dampak Pernikahan Beda Agama Terhadap Pendidikan Anak}

Seorang muslim/muslimah yang cerdas sudah pasti tidak akan gegabah

50 Muslim bin Al-Hajjaj. (1415 H/1994 M). Shahih Muslim, Juz IX. Beirut: Darul Kutub Al-Ilmiyyah Libanon. hlm. 31.

51 Abu Daud. (t.t.). Sunan Abu Dawud, Jilid I. Beirut: Dar Al-Fikr. hlm. 454. Lihat pula Ibnu Majah. (t.t.). Sunan Ibnu Majah, Juz I. Beirut: Dar Al-Fikr. hlm. 597. 
dalam menentukan pasangan hidupnya dia akan senantiasa berupaya dan berjuang untuk mencari pasangan suami/istri yang baik agama dan akhlaknya yang kelak menjadi pendidik sekaligus figur bagi anak-anaknya. Sebagaimana yang diungkapkan oleh seorang penulis buku, bahwa Seorang anak akan menurut tarbiyah dan pendidikan yang diberikan kepadanya, sifat-sifat orang tua akan menurun kepada anak-anak mereka, ibarat kata pepatah "buah jatuh tidak akan jauh dari pohonnya." Betapa banyak ketakwaan pada diri anak disebabkan dia mengikuti ketakwaan kedua orang tuanya atau salah seorang dari mereka. ${ }^{52}$

Allah S.W.T. berfirman dalam Surat At-Tahrim Ayat 6:

"Hai orang-orang yang beriman, peliharalah dirimu dan keluargamu dari api neraka yang bahan bakarnya adalah manusia dan batu; penjaganya malaikat-malaikat yang kasar, keras, dan tidak mendurhakai Allah terhadap apa yang diperintahkan-Nya kepada mereka dan selalu mengerjakan apa yang diperintahkan."

Kedua orang tua dan guru bertanggung jawab terhadap pendidikan generasi muda. Jika pendidikan mereka

${ }^{52}$ Ummu Ihsan Choiriyah dan Abu Ikhsan Al-Atsary. (2012). hlm. 24. baik, maka berbahagialah generasi tersebut di dunia dan akhirat, tapi jika mereka mengabaikan pendidikannya maka sengsaralah generasi tersebut dan beban dosanya berada pada leher mereka. $^{53}$

Rosulullah S.A.W. bersabda:

"Setiap orang dari kalian adalah pemimpin, dan setiap kalian bertanggung jawab atas siapa yang dipimpinnya" (H.R. Al-Bukhari dan Muslim) ${ }^{54}$

Dan juga merupakan kabar gembira bagi kedua orang tua manakala dia mendidik anaknya hingga menjadi anak yang sholih karena ia akan menjadi aset bagi kedua orang tuanya di akhirat kelak.

$$
\begin{aligned}
& \text { ((عن أبي هريرة رضي الله عنه أن } \\
& \text { رسوَ الله صلى الله عليه واله وسلم قَاً: }
\end{aligned}
$$



$$
\begin{aligned}
& \text { من ثُلثة إلَّ من صدقة جارية أو علم } \\
& \text { ينتفع به أو ولد صالخ يدعو له.)) } \\
& \text { (صحيح مسلم) (9.) }
\end{aligned}
$$

“Apabila Manusia meninggal Dunia maka terputuslah amalnya kecuali karena tiga hal, 1. Shadaqah jariyah, 2. Ilmu yang bermanfaat, atau 3. Anak shaleh yang

53 Muhammad bin Jamil Zainu. (2011). Bimbingan Islam untuk Priadi dan Masyarakat. Jakarta: Darul Haq. hlm. 89.

54 Muhammad bin Jamil Zainu. (2011). hlm. 89 . 
mendoakannya".

(H.R.

Muslim).

Maka setiap pendidik hendaknya melakukan perbaikan dirinya terlebih dahulu, karenaperbuatan baik bagi anak-anak adalah yang dikerjakan oleh pendidik. Dan perbuatan jelek bagi anak-anak adalah yang ditinggalkan oleh pendidik. Karenanya sikap baik guru dan orang tua di depan anak-anak merupakan pendidikan anak yang paling utama. 55

Pernikahan beda agama akan berdampak negatif bagi pendidikan anak-anak dan generasi selanjutnya. Sebab, orang tua adalah figur utama dari anak-anaknya. Jika orang tuanya bukan seorang muslim, bagaimana mungkin bisa menjadikan anak-anaknya menjadi anak-anak yang sholih sebagai penerus generasi yang baik dan berprestasi di masa mendatang.

\section{KESIMPULAN}

Pernikahan beda agama itu tidaklah dapat membawa manfaat. Justru bisa jadi sebaliknya akan menjadikan kemudharatan bagi generasi mendatang. Sebab menyatukan dua pemikiran yang seakidah saja belum tentu bisa semudah

55 Muhammad bin Jamil Zainu. (2011). yang dibayangkan apa lagi jika menyatukan dua pemikiran yang berbeda keyakinannya. Hal ini akan berdampak negatif baik bagi keutuhan rumah tangga, keyakinan maupun pendidikan anak, kecuali jika tujuannya adalah untuk menyelamatkan wanita ahlul kitab agar mereka mendapat hidayah dari Allah S.W.T.

Allah dan Rasul-Nya sangat menekankan untuk berhati-hati dalam hal memilih pasangan hidup, sebab memilih pasangan yang salah dapat mendatangkan bencana bagi keluarga itu sendiri lantaran pasangan hidup yang dipilihnya tidak faham permasalahan agama atau bahkan tidak seakidah yang kemudian akan melahirkan generasigenerasi yang tidak mendapatkan pendidikan Islam dengan baik, Allah S.W.T. melarang laki-laki mukmin menikah dengan wanita musyrik meskipun mereka (wanita-wanita) itu sangat menarik, cantik ataupun kaya, kecuali jika mereka telah beriman.

\section{DAFTAR PUSTAKA}

\section{Sumber dari Buku}

Abdullah. (2007). Ali Yatim Agama dan Ilmu Perbandingan. Bandung: Nuansa Aulia. hlm. 90 . 
Abdurrahman Ad-Dimasyqi, M. (2014). Fiqih Empat Madzhab. Bandung: Hasyimi.

Al-Hajjaj, M. (1415 H/1994 M). Shahih Muslim, Juz IX. Beirut: Darul Kutub Al-Ilmiyyah Libanon.

As-Sayyid Salim, A.M.K. (2014). Shahih Fiqh Sunnah wa Adillatuhu wa Taudhih Madzahib AlA'imah/Shahih Fikih Sunnah. Jakata: Pustaka Azzam.

Azzam, A.A.M. dan Hawwas, A.W.S. (2009). Fiqh Munakahat. Jakarta: Amzah.

Az-Zuhaili, W. (2011). Fiqih Islam wa Adillatuhu. Jakarta: Gema Insani.

Badawi, A.A. (2008). Fiqih Praktis Nikah. Tasikmalaya: Salwa Press.

Berkatullah, A.H. dan Prasetyo, T. (2006). Hukum Islam Menjawab Tantangan Zaman yang Terus Berkembang. Yogyakarta: Pustaka Pelajar.

Choiriyah, U.I. \& Al-Atsary, A.I. (2012). Mencetak Generasi Rabbani. Bogor: Darul Ilmi Publishing.

Daud, A. (t.t.). Sunan Abu Daud, Jilid I. Beyrut: Dar Al-Fikr.

Direktorat Pembinaan Badan Peradilan Agama Islam, Direktorat Jenderal Pembinaan Kelembagan Islam Departemen Agama. (1985). Kenang-kenangan Seabad Peradilan Agama di Indonesia. Jakarta.

Ghazali, M.B. (1992). Perbandingan Mazhab. Jakarta: PT Ihtiar Baru Van Hoeve.
Ghazali, M.B. (1999). Ensikloedia Islam. Jakarta: PT Ihtiar Baru Van Hoeve.

Hawari, D. (1997). Ilmu Kedokteran jiwa dan Kesehatan Jiwa. Yogyakarta: Dana Bhakti Prima Yasa.

Ibnu Majah. (t.t.). Sunan Ibnu Majah, Juz I. Beirut: Dar Al-Fikr.

Mahjuddin. (2012). Masa'il Al-Fiqh, Kasus-Kasus Aktual dalam Hukum Islam. Jakarta: Kalam Mulia.

Ma'luf, L. (1986). Al-Munjid. Beirut: Daar Al-Masyriq.

R. Djamali, A. (2005). Pengantar Hukum Indonesia. Jakarta: PT Raja Grafindo Persada.

Sabiq, S. (1980). Fiqih Sunnah. Bandung: PT Al Ma'arif.

Saleh, K.W. (1992). Hukum Perkawinan Indonesia. Jakarta: Ghalia.

Shomad, A. (2012). Hukum Islam Penormaan Prinsip Syari'ah dalam Hukum Indonesia. Jakarta: Kencana Media Prenada Group.

Syafi'i. (2010). Ringkasan Kitab AlUmm. Jakarta: Pustaka Azzam.

Syarifuddin, A. (2009). Hukum Perkawinan di Indonesia. Jakarta: Kencana Prenada Media Grup.

Tim Redaksi Nuansa Aulia. (2011). Kompilasi Hukum Islam. Bandung: Nuansa Aulia.

Trisnaningsih, M. (2007). Relevansi Kepastian Hukum dalam Mengatur Perkawinan Beda Agama di Indonesia. Bandung: Penerbit Utomo. 
UUP No. 1 Tahun 1974.

Wahyuni, S. (2011). Kontroversi Perkawinan Beda Agama di Indonesia. Media Syariah, Vol. XIII.

Yahya Al-Faif, S.A. (2009). Ringkasan Fikih Sunnah Sayyid Sabiq. Jakarta: Pustaka Al-Kautsar.

Yanggo, H.T. (2005). Masail Fiqiyyah. Bandung: Penerbit Angkasa Bandung.

Zainu, M.J. (2011). Bimbingan Islam untuk priadi dan masyarakat. Jakarta: Darul Haq.

\section{Sumber dari Internet}

http://rodlial.blogspot.com/2012/04/mak alah- substansi- hukum- positifdi.html, hari Selasa tgl 11 Agustus 2015 pkl. 14:30 WIB.

https://id.wikipedia.org/wiki/Mazhab\#ci te_note-mediamuslim-1, hari Selasa tgl 11 Agustus 2015 pkl. 13:30 WIB.

http://ading-aday.blogspot. com/p/blogpage.html, hari Rabu 12 Agustus 2015, pkl. 09:30 WIB. 